\title{
Reduced levels of T-helper 17-associated cytokines in the serum of patients with breast cancer: indicators for following the course of disease
}

\author{
RASOUL BAHARLOU ${ }^{1}$, MOHAMMAD REZA ATASHZAR ${ }^{l}$, ABBAS AHMADI VASMEHJANI, \\ EBARAHIM RAHIMI ${ }^{2}$, MAJID KHOSHMIRSAFA ${ }^{l}$, FARHAD SEIF ${ }^{1}$, MARYAM MAHDIYAR $^{3}$ \\ ${ }^{1}$ Department of Immunology and Microbiology, School of Medicine, Jahrom University of Medical Sciences, Jahrom, Iran \\ ${ }^{2}$ Department of Social Medicine, School of Medicine, Jahrom University of Medical Sciences, Jahrom, Iran \\ ${ }^{3}$ Department of Student Research Committee, School of Medicine, Jahrom University of Medical Sciences, Jahrom, Iran
}

\begin{abstract}
Interleukin (IL)-17-producing $C D 4^{+}$Thelper (Th17) cells that are known to produce IL-17 have recently been defined as a unique subset of proinflammatory helper cells. Interleukin 17 is an inflammatory cytokine with robust effects on many cells. It can play important roles in the pathogenesis of diverse groups of immune-mediated diseases. In this regard, the present case-control study aimed at determining serum levels of $I L-17, I L-6$, and transforming growth factor $\beta(T G F-\beta)$ in Iranian breast cancer patients. Blood samples were collected from 55 patients with breast cancer and 34 healthy individuals with no history of malignancies or autoimmune disorders, based on simple sampling. The serum levels of IL-17, IL-6 and TGF- $\beta$ were measured by enzyme-linked immunosorbent assay (ELISA). The serum level of IL-6 was significantly lower in patients with breast cancer compared with healthy individuals $(p=0.0003)$, and also the IL-17 was lower in the patient group than in controls $(p=0.01)$. Interestingly, the TGF- $\beta$ serum level in patients was less than in controls $(p<0.0001)$. As most of the cases investigated in this study were in their early stages, it can be concluded that reduced IL-17,IL-6, and $T G F-\beta$ can be used as predictors for clinical stage and prognosis of cancers such as breast carcinoma.
\end{abstract}

Key words: breast cancer, interleukin 6, interleukin 17, T-helper 17, transforming growth factor $\beta$.

(Cent Eur J Immunol 2016; 41 (1): 78-85)

\section{Introduction}

Two decades ago, Mossman et al. [1] proposed that $\mathrm{CD}^{+} \mathrm{T}$ cells differentiate into two subsets with reciprocal functions and patterns of cytokine secretion, termed T-helper 1 (Th1) and Th2 [2]. Th1 cells are characterised by production of interferon- $\gamma($ IFN- $\gamma$ ), and they induce cell-mediated immunity against intracellular pathogens, while Th2 cells produce interleukin (IL)- 4 and stimulate humeral immunity against parasitic helminths. This paradigm was maintained until 2005, when a third T-cell subset, known as Th17, was identified [3]. Th17 was reported with its major signature of releasing IL-17 [4]. In recent years, growing reports on the role and function of Th17 indicate that this subset of CD4+ T cells plays a fundamental role in infiltration and recruitment of inflammatory cells against intercellular parasites and fungi [5, 6]. Also, recent data in humans suggest that Th17 cells are important due to their strong association with a diverse group of immune-mediated diseases, including psoriasis, rheumatoid arthritis, multiple sclerosis, inflammatory bowel disease, cancers, and other autoimmune diseases. Moreover, they seem to be important for controlling these disorders, too [7, 8]. During tumour development, Th17 cells gradually increase in the tumour microenvironment. There are several factors that can play major roles in the induction of Th17 differentiation. These factors include a lot of substances released by tumour cells and tumour stroma, or molecules secreted by tumour-infiltrating immune cells such as transforming growth factor $\beta$ (TGF- $\beta$ ), IL-6, prostaglandin $\mathrm{E}_{2}\left(\mathrm{PGE}_{2}\right), \mathrm{IL}-21, \mathrm{IL}-23$, osteopontin, IL-1 $\beta$, and tumour necrosis factor $\alpha$ (TNF- $\alpha$ ) [9-11]. Several recent studies have demonstrated that TGF- $\beta$ and IL- 6 are critical factors for murine and human Th17 cell differentiation in vitro. The role of TGF- $\beta$ in human Th17 cells is still subject to intense debate. In humans, naive $\mathrm{T}$ helper cells can be induced to differentiate into Th17

Correspondence: Mohammad Reza Atashzar, Department of Immunology and Microbiology, School of Medicine, Jahrom University of Medical Sciences, Jahrom, Iran, tel. +98 936526 7697, fax +98 791334 1509, e-mail: Mr.atashzar@yahoo.com Submitted: 8.07.2015; Accepted: 30.10.2015 
cells in vitro by exposure to IL-6 and TGF- $\beta$, also IL-23 promotes proliferation and survival of these cells [12-14]. However, some studies found that the role of TGF- $\beta$ in differentiation of human Th17 cells to be inhibitory $[15,16]$.

It is obvious that TGF- $\beta$ plays an essential role in differentiation of $\mathrm{CD}^{+} \mathrm{T}$ cells toward regulatory $\mathrm{T}$ cells (Tregs) or Th17 cells. The combination of TGF- $\beta$ and IL-6 promotes the differentiation of Th17 cells and inhibits Treg cell differentiation $[9,14,17]$, whereas TGF- $\beta$ plus retinoic acid inhibits Th17 cell differentiation and promotes the Treg cells $[18,19]$.

There are some studies that show the paradoxes of the protumour and antitumour functions of IL-17. Studies have shown that IL-17 can increase growth and proliferation of cervical cancer cells through IL-6 [20], it can increase blood vessels in ovarian cancer [21], and it has been noticed as a prognostic biomarker in colorectal cancer progression [22]. On the other hand, antitumor functions of IL-17 have been reported. In this connection, Muranski et al. reported that Th17 cells are more effective than Th1 cells in eliminating established tumours [23]. In addition, IL-17 induces the production of IL- 6 from a variety of cells. Interleukin 17, via IL-6 and IL-12, is associated with the induction of tumour-specific cytotoxic T lymphocyte (CTL) induction [24] and affects the overexpression of major histocompatibility complex (MHC) classes I and II in dendritic cell maturation [25].

Breast cancer is the most common cancer among Iranian females, with a mean age onset at least 10 years below than seen in western countries [26]. The role of Th17 cells in the pathogenesis of breast cancer is pivotal.

Due to the importance of IL-6, TGF- $\beta$, and IL-17 serum levels in breast cancer disease, we used ELISA to directly measure their serum levels in peripheral blood cells of patients with breast cancer to compare them with healthy blood donors.

\section{Material and methods}

\section{Subjects}

Seventy-one women who participated in this study were diagnosed with infiltrating ductal carcinoma of the breast, confirmed by histological studies using simple sampling. Fifty-five patients were selected with a mean age of $48 \pm 10$ years, and the rest were excluded from the study because of technical errors in the ELISA method. Patients from the hospitals of Shiraz University of Medical Sciences (Shiraz, Iran) were referred to our laboratory in the Institute for Cancer Research (ICR), which was used as the cancer referral laboratory. Peripheral blood samples $(2 \mathrm{ml})$ were collected before any clinical intervention. Data on age, tumour histology, tumour size, tumour invasion, clinical stage, histological grade, and the presence of other organ metastases were obtained from the hospital pathological records of the patients. The clinical stage was determined with the tumour-node-metastasis (TNM) classification. The TNM classification and tumour diameter were obtained from the pathology reports by one pathologist. In addition, the tumours were graded according to the World Health Organization (WHO) classification criteria as moderately or poorly differentiated. Patients received chemotherapy interventions before this study. Table 1 demonstrates the distribution of patients regarding different clinical criteria. Blood samples from 34 healthy individuals with a mean age of $44 \pm 7$ years without history of malignancies or autoimmune disorders were also obtained as the control group. During sample collection, it was en-

Table 1. Distribution of patients with breast cancer with regard to different clinical criteria

\begin{tabular}{|c|c|c|}
\hline Pathological characteristic & Status & Frequency $n(\%)$ \\
\hline \multirow[t]{2}{*}{ Side } & Left & $29(52)$ \\
\hline & Right & $26(48)$ \\
\hline \multirow[t]{2}{*}{ ER } & Positive & $37(68)$ \\
\hline & Negative & $18(32)$ \\
\hline \multirow[t]{2}{*}{ PR } & Positive & $34(62)$ \\
\hline & Negative & $21(38)$ \\
\hline \multirow[t]{2}{*}{ HER-2 } & Positive & $37(68)$ \\
\hline & Negative & $18(32)$ \\
\hline \multirow[t]{2}{*}{ Necrosis } & Positive & $25(45)$ \\
\hline & Negative & $30(55)$ \\
\hline \multirow[t]{2}{*}{ Calcification } & Positive & $37(67)$ \\
\hline & Negative & $18(33)$ \\
\hline \multirow[t]{2}{*}{ Lymphatic invasion } & Positive & $24(43)$ \\
\hline & Negative & $31(57)$ \\
\hline \multirow[t]{2}{*}{ Vascular invasion } & Positive & $11(20)$ \\
\hline & Negative & $44(80)$ \\
\hline \multirow[t]{2}{*}{ Perineural invasion } & Positive & $11(20)$ \\
\hline & Negative & $44(80)$ \\
\hline \multirow[t]{2}{*}{ Grade } & Low & $47(86)$ \\
\hline & High & $8(14)$ \\
\hline \multirow[t]{4}{*}{ Stage } & I & $18(33)$ \\
\hline & II & $26(48)$ \\
\hline & III & $9(16)$ \\
\hline & IV & $2(3)$ \\
\hline \multirow[t]{2}{*}{ Metastasis } & Positive & $2(97)$ \\
\hline & Negative & $53(3)$ \\
\hline
\end{tabular}


sured that subjects had neither infection nor any acute or chronic diseases. All the subjects provided informed consent to participate in the study and to allow their biological samples to be analysed. Approval for the study was given by the Ethics Committee of Shiraz University of Medical Sciences (Shiraz, Iran).

\section{Enzyme linked immunosorbent assay (ELISA)}

The amounts of cytokines in the patients' and controls' sera were measured at the same time by the same technician, using ELISA-kits (eBiosciences, San Diego, CA, USA). Briefly, premixed standards were reconstituted in

$\mathbf{A}$
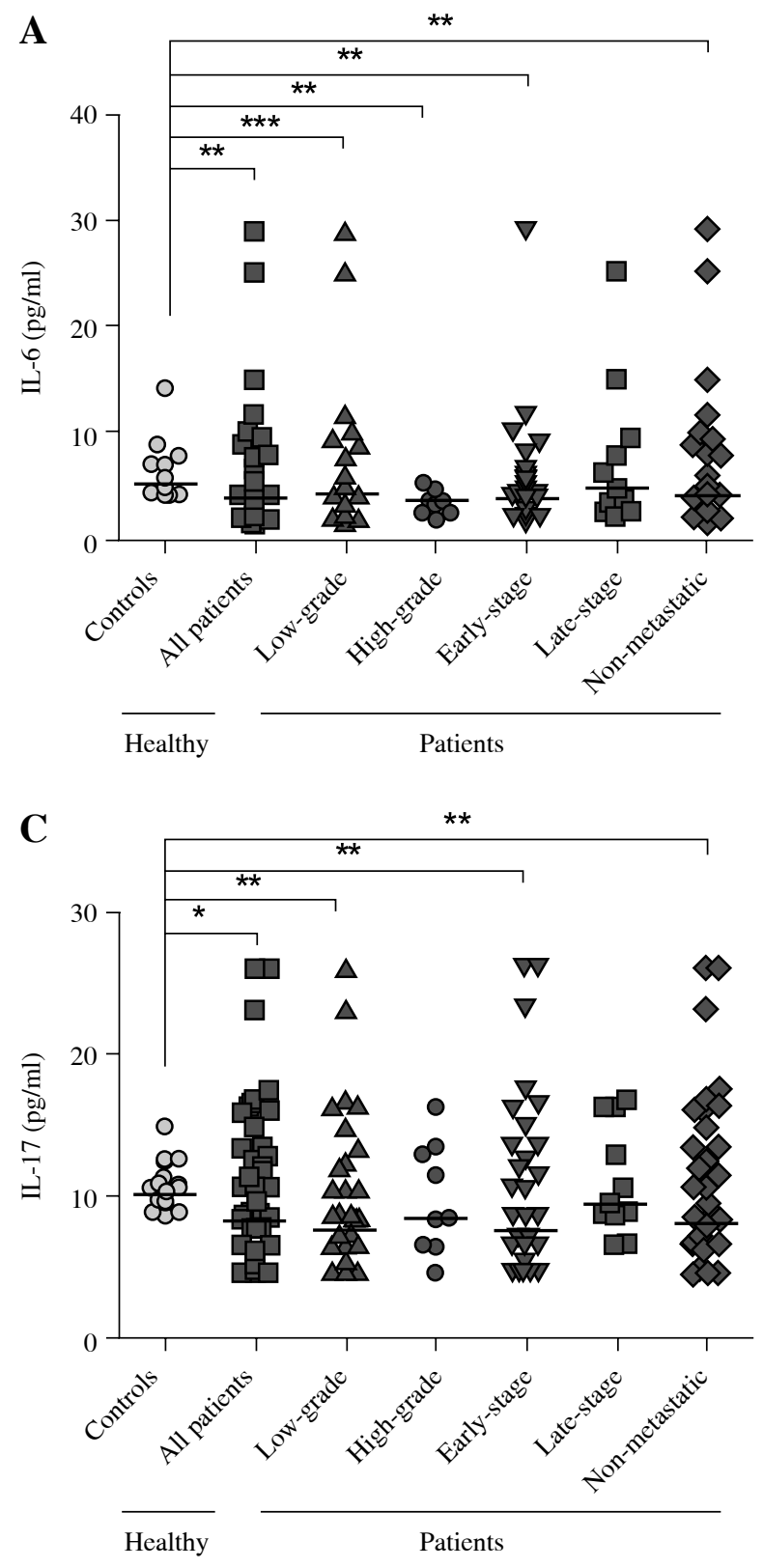

PBS (pH 7.2), generating stock concentrations of 200, 500, and $1000 \mathrm{pg} / \mathrm{ml}$ for IL-6, IL-17, and TGF- $\beta$, respectively. Sensitivity for IL-17, IL-6, and TGF- $\beta$ were 4 , 2 , and $8 \mathrm{pg} / \mathrm{ml}$, respectively. The standard stocks were serially diluted in Reagent Diluent to generate seven points for the standard curves. Diluted Capture Antibody was added at the final volume of $100 \mu \mathrm{l}$. Plates were sealed and incubated overnight at room temperature, then they were washed with Wash Buffer. Premixed standards or samples (100 $\mu \mathrm{l})$ were added to each well, covered with an adhesive strip, and incubated overnight at $4{ }^{\circ} \mathrm{C}$. After incubation and washing, $100 \mu \mathrm{l}$ of the premixed Detection Antibody was added

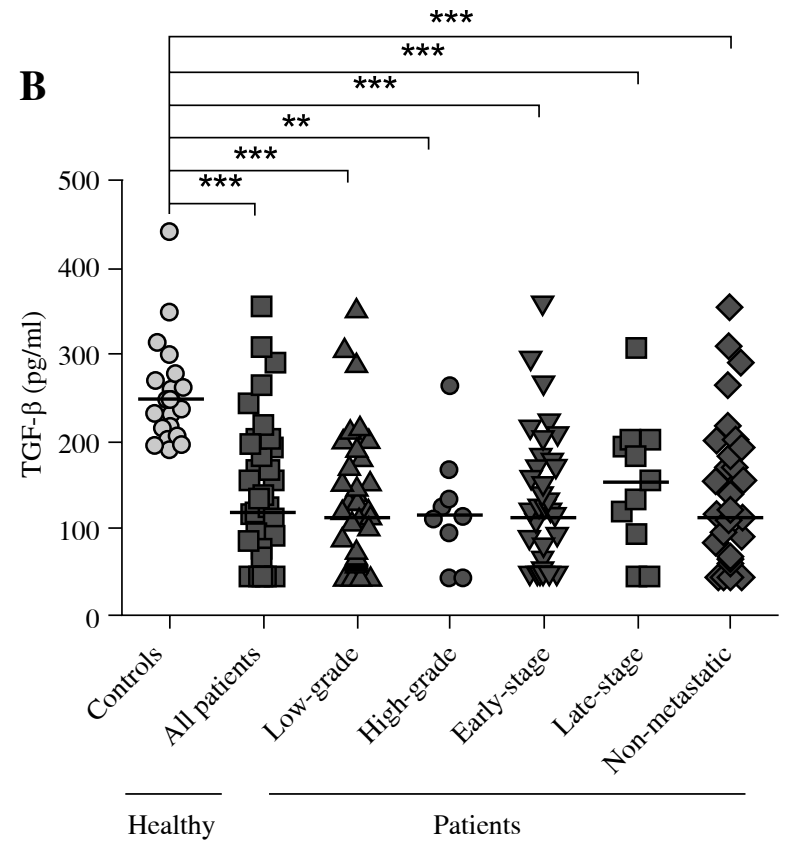

$* p<0.05, * * p<0.01, * * * p<0.0001$

Fig. 1. Serum level of IL-6, TGF- $\beta$, and IL-17 in the peripheral blood of breast cancer patients and normal controls. Significant differences were found in the serum level of IL-6 (A), TGF- $\beta$ (B), and IL-17 (C) in peripheral blood of patients with breast cancer patients compared to healthy controls. Presented data were analysed with the nonparametric two-tailed Mann-Whitney test; the horizontal lines show the median of the groups 
Table 2. The serum levels of IL-6, TGF- $\beta$, and IL-17 in peripheral blood of patients with breast cancer and normal individuals $^{\mathrm{a}, \mathrm{b}}$

\begin{tabular}{|c|c|c|c|c|c|c|c|c|c|}
\hline & \multicolumn{3}{|c|}{ IL-6 } & \multicolumn{3}{|c|}{ TGF- $\beta$} & \multicolumn{3}{|c|}{ IL-17 } \\
\hline & Mean \pm SEM & Median & $p$ & Mean \pm SEM & Median & $p$ & Mean \pm SEM & Median & $p$ \\
\hline $\begin{array}{l}\text { Controls } \\
(n=34)\end{array}$ & $5.70 \pm 0.31$ & 5.13 & & $249.4 \pm 8.05$ & 247.7 & & $10.17 \pm 0.21$ & 10.0 & \\
\hline $\begin{array}{l}\text { All patients } \\
(n=55)\end{array}$ & $5.30 \pm 0.67$ & 3.74 & 0.0003 & $130.1 \pm 10.11$ & 118.1 & $<0.0001$ & $9.67 \pm 0.71$ & 8.05 & 0.01 \\
\hline $\begin{array}{l}\text { Low-grade } \\
(n=38)\end{array}$ & $5.80 \pm 0.91$ & 4.14 & 0.007 & $126.3 \pm 12.78$ & 111.8 & $<0.0001$ & $8.94 \pm 0.82$ & 7.40 & 0.001 \\
\hline $\begin{array}{l}\text { High-grade } \\
(n=17)\end{array}$ & $4.18 \pm 0.76$ & 3.47 & 0.0002 & $138.8 \pm 16.12$ & 133.0 & 0.0002 & $11.35 \pm 1.35$ & 9.27 & $>0.05$ \\
\hline $\begin{array}{l}\text { Early-stage } \\
(n=42)\end{array}$ & $4.84 \pm 0.67$ & 3.71 & $<0.0001$ & $120.2 \pm 11.24$ & 111.8 & $<0.0001$ & $9.26 \pm 0.86$ & 7.40 & 0.003 \\
\hline $\begin{array}{l}\text { Late-stage } \\
(n=13)\end{array}$ & $7.45 \pm 2.11$ & 4.59 & $>0.05$ & $152.4 \pm 23.26$ & 154.2 & $<0.0001$ & $10.92 \pm 1.16$ & 9.27 & $>0.05$ \\
\hline $\begin{array}{l}\text { Non-metastatic } \\
(n=53)\end{array}$ & $5.46 \pm 0.72$ & 3.90 & 0.0008 & $125.2 \pm 10.48$ & 113.9 & $<0.0001$ & $9.52 \pm 0.75$ & 7.83 & 0.003 \\
\hline
\end{tabular}

to each well and incubated for two hours at room temperature. After incubation and washing, Streptavidin-HRP was added to each well $(100 \mu \mathrm{l})$. The incubation was terminated after 20 minutes at room temperature. Then, $50 \mu$ of Stop Solution was added to each well, and the optical density of each well was immediately determined using a microplate reader set to $450 \mathrm{~nm}$. The results were expressed in $\mathrm{pg} / \mathrm{ml}$.

\section{Statistical analysis}

The amounts of IL- 6 , TGF- $\beta$, and IL- 17 in the peripheral blood were evaluated to the corresponding values from control samples with nonparametric Kruskal-Wallis and Mann-Whitney tests by SPSS software version 11.5 (SPSS, Chicago, IL, 173 USA). Finally, correlations between different statuses were evaluated using Spearman correlation coefficient. The variable levels were evaluated using Prism 4 software (Inc; San Diego CA, USA, 2003). $P<0.05$ was regarded as significant in all statistical analysis.

\section{Results}

\section{Serum cytokine level in patient and healthy groups}

It was shown that the serum level of IL-6 among patients was significantly low compared to the control group (Fig. 1A). We noted significant differences in the lowgrade, high-grade, early disease stages (stages I and II), and non-metastatic status compared to controls. These results are summarised in Table 2 . In addition, no correlation was found between IL-6 serum level and clinicopathological data of the cases (data not shown). Interleukin 6 was not significantly related to depth of tumour, and there were no significant differences between negative and positive invasion status (Table 3).

As shown in Fig. 1B, specimens in the control group showed substantially higher levels of TGF- $\beta$ than all of those from the patients (Table 2). In addition, among the patients in low-grade, high-grade, early disease stages (stages I and II), late disease stages, and non-metastasis status, the serum level of IL-6 was lower than in healthy volunteers.

The IL-17 serum level showed a significantly lower level among patients compared to the control group. Remarkably, patients in low-grade, early-stage, and non-metastatic status of the disease showed significant differences in the mean serum level of IL-17 (Fig. 1C). Nevertheless, no correlation was found between IL-17 serum level and any clinicopathological parameters in the patient group (data not shown). In addition, patients in none of clinicopathological parameters showed significant differences in cytokine level. These results are summarised in Table 3.

Our study was extended by performing the correlation analysis between IL- 6 and TGF- $\beta$ serum level with IL-17 concentration in patient and control groups (Fig. 2). The IL-17 serum level positively correlated with the IL-6 level in the control group $(r=0.51, p=0.001)$.

\section{Discussion}

Current understanding about IL-17 reveals that it is produced from Th17 cells and plays a crucial role in inflammation. It has also been shown that this cytokine plays an important role in allergies and autoimmune dis- 
Table 3. The serum level of IL-6, TGF- $\beta$, and IL-17 in different clinic pathological parameters of patients with breast cancer

\begin{tabular}{|c|c|c|c|c|c|c|c|c|c|}
\hline & \multicolumn{3}{|l|}{ IL-6 [pg/ml] } & \multicolumn{3}{|c|}{ TGF- $\beta$ [pg/ml] } & \multicolumn{3}{|c|}{ IL-17 [pg/ml] } \\
\hline & Mean \pm SEM & Median & $p$ & Mean \pm SEM & Median & $p$ & Mean \pm SEM & Median & $p$ \\
\hline \multicolumn{10}{|c|}{ Lymphatic invasion } \\
\hline Negative & $4.89 \pm 0.88$ & 3.37 & NS & $120.9 \pm 13.31$ & 111.8 & NS & $9.38 \pm 0.97$ & 7.69 & NS \\
\hline Positive & $6.24 \pm 1.19$ & 4.81 & & $135.8 \pm 16.76$ & 124.5 & & $10.13 \pm 1.15$ & 8.63 & \\
\hline \multicolumn{10}{|c|}{ Vascular invasion } \\
\hline Negative & $5.53 \pm 0.87$ & 3.93 & NS & $125.3 \pm 12.48$ & 111.8 & NS & $9.69 \pm 0.92$ & 7.69 & NS \\
\hline Positive & $4.99 \pm 1.09$ & 3.47 & & $130.9 \pm 17.64$ & 128.7 & & $9.56 \pm 0.97$ & 8.99 & \\
\hline \multicolumn{10}{|c|}{ Perineural invasion } \\
\hline Negative & $5.04 \pm 0.86$ & 3.47 & NS & $125.1 \pm 12.98$ & 116.0 & NS & $10.1 \pm 0.77$ & 7.69 & NS \\
\hline Positive & $6.65 \pm 1.45$ & 4.81 & & $138.9 \pm 19.92$ & 126.6 & & $9.01 \pm 0.87$ & 8.41 & \\
\hline \multicolumn{10}{|l|}{ ER } \\
\hline Negative & $3.67 \pm 0.26$ & 3.47 & NS & $95.37 \pm 13.35$ & 90.62 & NS & $9.87 \pm 1.33$ & 7.40 & NS \\
\hline Positive & $5.83 \pm 0.89$ & 4.43 & & $147.8 \pm 14.64$ & 143.6 & & $10.07 \pm 0.97$ & 8.34 & \\
\hline \multicolumn{10}{|l|}{ PR } \\
\hline Negative & $5.10 \pm 1.14$ & 3.74 & NS & $108.5 \pm 15.25$ & 103.3 & NS & $10.40 \pm 1.23$ & 8.4 & NS \\
\hline Positive & $4.85 \pm 0.54$ & 3.53 & & $135.3 \pm 14.36$ & 116.0 & & $9.53 \pm 0.97$ & 7.69 & \\
\hline \multicolumn{10}{|l|}{ HER-2 } \\
\hline Negative & $5.76 \pm 0.94$ & 4.43 & NS & $109.4 \pm 18.05$ & 99.08 & NS & $9.72 \pm 1.17$ & 9.85 & NS \\
\hline Positive & $5.06 \pm 0.99$ & 3.32 & & $141.4 \pm 16.56$ & 149.9 & & $10.10 \pm 1.16$ & 8.12 & \\
\hline \multicolumn{10}{|l|}{ Necrosis } \\
\hline Negative & $6.66 \pm 1.45$ & 3.71 & NS & $124.6 \pm 15.62$ & 116.0 & NS & $9.43 \pm 0.98$ & 8.12 & NS \\
\hline Positive & $4.30 \pm 0.36$ & 3.98 & & $135.7 \pm 14.88$ & 122.4 & & $10.15 \pm 1.23$ & 8.63 & \\
\hline \multicolumn{10}{|c|}{ Calcification } \\
\hline Negative & $6.33 \pm 1.16$ & 4.11 & NS & $135.4 \pm 12.05$ & 128.7 & NS & $10.19 \pm 1.05$ & 8.41 & NS \\
\hline Positive & $4.16 \pm 0.44$ & 3.53 & & $121.7 \pm 22.08$ & 94.85 & & $9.195 \pm 1.19$ & 7.40 & \\
\hline \multicolumn{10}{|l|}{ Involvement } \\
\hline Right & $5.11 \pm 0.64$ & 3.95 & NS & $137.7 \pm 17.83$ & 116.0 & NS & $9.41 \pm 1.05$ & 8.12 & NS \\
\hline Left & $5.68 \pm 1.24$ & 3.53 & & $118.8 \pm 11.98$ & 122.4 & & $9.92 \pm 1.08$ & 7.83 & \\
\hline \multicolumn{10}{|l|}{ Grade } \\
\hline Low & $5.80 \pm 0.91$ & 4.14 & NS & $126.3 \pm 12.78$ & 111.8 & NS & $8.94 \pm 0.82$ & 7.40 & NS \\
\hline High & $4.18 \pm 0.76$ & 3.47 & & $138.8 \pm 16.12$ & 133.0 & & $11.35 \pm 1.35$ & 9.27 & \\
\hline \multicolumn{10}{|l|}{ Stage } \\
\hline Early & $4.84 \pm 0.67$ & 3.71 & NS & $120.2 \pm 11.24$ & 111.8 & NS & $9.26 \pm 0.86$ & 7.40 & NS \\
\hline Late & $7.45 \pm 2.11$ & 4.59 & & $152.4 \pm 23.26$ & 154.2 & & $10.92 \pm 1.16$ & 9.27 & \\
\hline \multicolumn{10}{|l|}{ Metastasis } \\
\hline Negative & $5.46 \pm 0.72$ & 3.90 & NS & $125.2 \pm 10.48$ & 113.9 & NS & $9.52 \pm 0.75$ & 7.83 & NS \\
\hline Positive & $3.20 \pm 0.58$ & 3.05 & & $193.5 \pm 22.77$ & 198.8 & & $11.62 \pm 1.72$ & 11.51 & \\
\hline
\end{tabular}

NS-not significant 

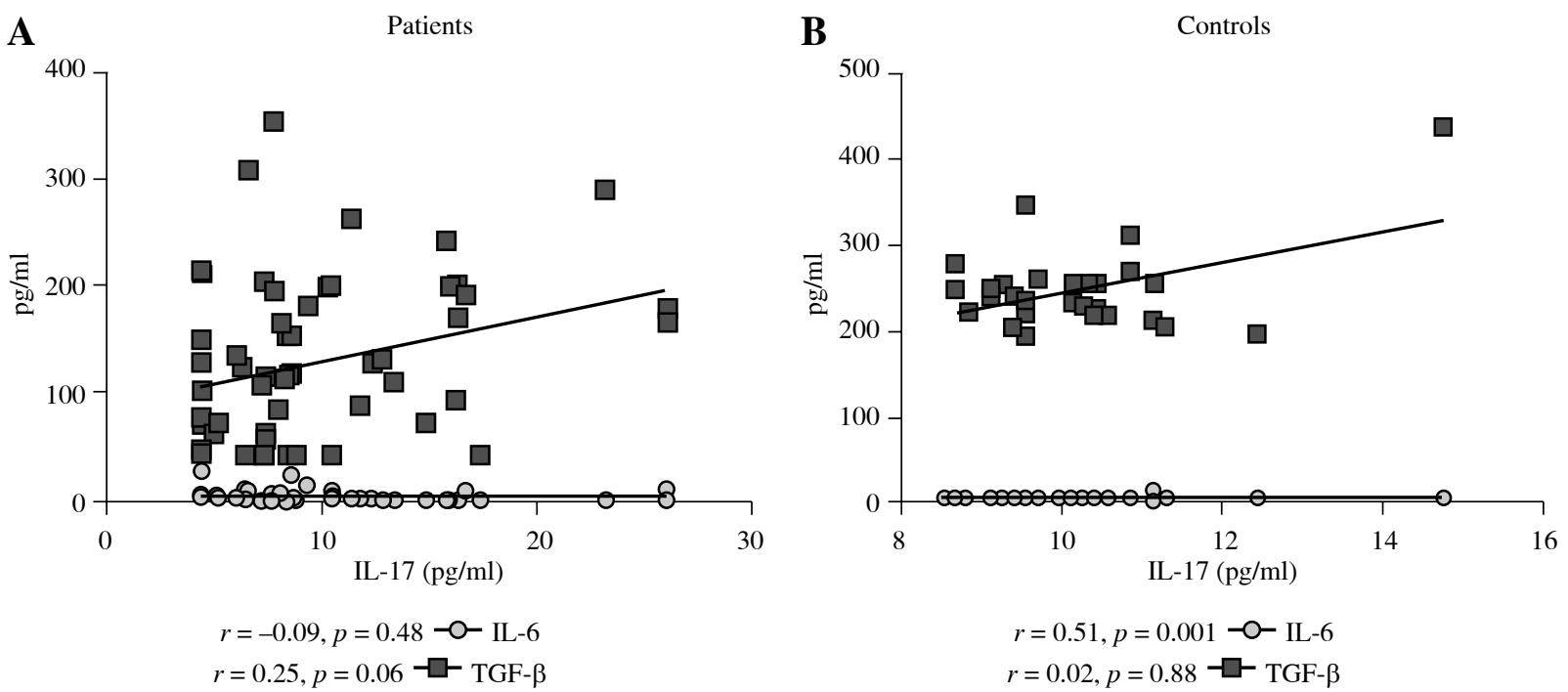

Fig. 2. The correlation between serum level of IL-6 and TGF- $\beta$ with IL-17 in the peripheral blood of patients with breast cancer and healthy individuals. The IL-17 serum level positively correlates with IL-6 level in control group $(r=0.51$, $p=0.001)$. Results were analysed with the Spearman test

eases $[27,28]$. One of the most important cytokines in the development of Th17 is TGF- $\beta$, which stimulates the formation of Treg cells. However, a combination of IL-6 and TGF- $\beta$ plays a leading role in the differentiation and development of Th17 cells [29]. In addition to its important physiological roles, the roles of Th17 are considerable in both pathological conditions including cancer and autoimmune disorders $[8,27]$. In the present study the levels of IL-17, IL-6, and TGF- $\beta$ as the stimulators of Th-17 differentiation in peripheral blood of patients with breast cancer were measured. Our findings revealed that the serum level of these cytokines were significantly decreased in patients in comparison with the control group. In addition, a positive correlation between IL- 6 and IL-17 was demonstrated. A number of studies have been done regarding IL-17 in different cancers. For instance, Baharlou's findings showed that IL-17 and TGF- $\beta$ were reduced in patients with bladder cancer, and that they can be important indicators for following the course and clinical stages of bladder carcinoma progression [30]. A study on IL-17 expression by Zhang et al. showed high expression levels of IL-17 and IL-23 mRNA in tumour tissues from patients with gastric cancer, suggesting that Th17 cell differentiation may increase in gastric cancer [31]. A different study also confirmed that IL-17 contributes to the growth of tumour via upregulation of proangiogenic and proinflammatory cytokines [32]. A study on ovarian cancer emphasised high expression of IL-17 with a significant role in tumour growth via angiogenesis [21]. Moreover, Wang et al. showed a significant increase of IL-17 and IL-6 mRNA expression in the tumour, which promoted tumour growth. It also seems that VEGF and
TGF- $\beta$ contribute to tumour progression by IL-17 [33]. However, a study by Radosavljevic et al. showed the lack of a significant relationship between serum level of IL-17 and colorectal cancer [34]. Kwon et al. also found no significant difference between IL-6 in controls and colorectal cancer patients [35]. However, Ravishankaran et al. proved the presence of a high serum level of IL-6 in breast cancer. Their study showed that preoperative high IL-6 levels were proposed as a poor prognostic factor for disease recurrence and overall survival in patients with breast cancer [36]. These findings suggest that both IL-6 and 17 are multi-functional cytokines that can promote growth of Th17 tumours.

There is a reciprocal effect between Th17 and Treg cells in regulation of the immune response [37]. The performance of each cell should be evaluated together, especially in growth or regression of the tumours [38]. According to our study, serum levels of IL-6, IL-17, and TGF- $\beta$ in early stages of breast cancer were significantly decreased in comparison with the control group, which can be interpreted as a reflection of reduced Th17 responses. Lower Th17-induced inflammation can be associated with a lack of angiogenesis. As explained, while cancer progresses particularly in late stages, with an increase in Th17 development, cancer may deteriorate.

Transforming growth factor $\beta$ is known to be released both by tumour and $\mathrm{T}$ regulatory cells during the late stages of most solid cancers [39]. Decreased serum levels of TGF- $\beta$ in the present study may be due to the fact that chemotherapy agents suppress tumour and Treg cells.

According to the presented data, it can be concluded that reduced serum levels of IL-6, IL-17, and TGF- $\beta$ in 
patients with the early stage of cancer indicates probable chemotherapy and radiotherapy suppressing effects on IL-17-producing Th17 cells and TGF- $\beta$-producing tumour cells in the early stage; however, with tumour progression, elevated IL-17-producing Th17 is expected.

Furthermore, in the late stages of cancer, which is associated with increased TGF- $\beta$, angiogenesis factors may worsen the cancer. Since cytokine serum levels in tumour tissue and peripheral blood are associated with each other, their concentration in serum can be a representation of immune responses in the tumour. Therefore, the cytokine profile in peripheral blood can be listed as an indicator following malignancy progress and immune response to cancer development. Also, using monoclonal antibodies against Th17-related cytokines can be considered as a suitable target for immune therapy of breast cancer in the final stages when the immune system is not competent against cancer. Finally, being aware of the precise balance between Th17 and Treg cells can help to provide new therapies against cancer, especially breast cancer.

\section{Acknowledgements}

The authors would like to thank the patients with breast cancer as well as the healthy individuals for their kind participation in this project. This study was financially supported by a grant from the Shiraz Institute for Cancer Research.

\section{The authors declare no conflict of interest.}

\section{References}

1. Mosmann TR, Cherwinski H, Bond MW, et al. (1986): Two types of murine helper $\mathrm{T}$ cell clone. Definition according to profiles of lymphokine activities and secreted. J Immunol 136: 2348-2357.

2. Murphy KM, Reiner SL (2002): The lineage decisions of helper T cells. Nat Rev Immunol 2: 933-944.

3. Harrington LE, Hatton RD, Mangan PR, et al. (2005): Interleukin 17-producing CD4+ effector T cells develop via a lineage distinct from the Thelper type 1 and 2 lineages. Nat Immunol 6: 1123-1132.

4. Xu S, Cao X (2010): Interleukin-17 and its expanding biological functions. Cell Mol Immunol 7: 164-174.

5. Peck A, Mellins ED (2009): Breaking old paradigms: Th17 cells in autoimmune arthritis. Clin Immunol 2009; 132: 295304.

6. Leipe J, Grunke M, Dechant C, et al. (2010): Role of Th17 cells in human autoimmune arthritis. Arthritis Rheum 62: 2876-2885.

7. Zambrano-Zaragoza JF, Romo-Martínez EJ, Durán-Avelar Mde J, et al. (2014): Th17 cells in autoimmune and infectious diseases. Int J Inflam 2014: 651503.

8. Tesmer LA, Lundy SK, Sarkar S, Fox DA (2008): Th17 cells in human disease. Immunol Rev 223: 87-113.

9. Nam JS, Terabe M, Kang MJ, et al. (2008): Transforming growth factor beta subverts the immune system into directly promoting tumor growth through interleukin-17. Cancer Res 68: 3915-3923.

10. Shime H, Yabu M, Akazawa T, et al. (2008): Tumor-secreted lactic acid promotes IL-23/IL-17 proinflammatory pathway. J Immunol 180: 7175-7183.

11. Lebrun JJ (2012). The dual role of TGF in human cancer: from tumor suppression to cancer metastasis. ISRN Mol Biol 2012: 1-28.

12. Zhou Z, Sun W, Liang Y, et al. (2012): Fenofibrate inhibited the differentiation of $\mathrm{T}$ helper 17 cells in vitro. PPAR Res 2012: 145654.

13. Volpe E, Servant N, Zollinger R, et al. (2008): A critical function for transforming growth factor- $\beta$, interleukin 23 and proinflammatory cytokines in driving and modulating human TH-17 responses. Nat Immunol 9: 650-657.

14. Manel N, Unutmaz D, Littman DR (2008): The differentiation of human TH-17 cells requires transforming growth factor- $\beta$ and induction of the nuclear receptor ROR $\gamma \mathrm{t}$. Nat Immunol 9: 641-649.

15. Wilson NJ, Boniface K, Chan JR, et al. (2007): Development, cytokine profile and function of human interleukin 17-producing helper T cells. Nat Immunol 8: 950-957.

16. Acosta-Rodriguez EV, Napolitani G, Lanzavecchia A, Sallusto $F$ (2007): Interleukins $1 \beta$ and 6 but not transforming growth factor- $\beta$ are essential for the differentiation of interleukin 17-producing human T helper cells. Nat Immunol 8: 942-949.

17. Passos ST, Silver JS, O’Hara AC (2010): IL-6 promotes NK cell production of IL-17 during toxoplasmosis. J Immunol 2010; 184: 1776-1783.

18. Mucida D, Cheroutre H (2007): TGFbeta and retinoic acid intersect in immune-regulation. Cell Adh Migr 1: 142-144.

19. Mucida D, Park Y, Kim G, et al. (2007): Reciprocal TH17 and regulatory $\mathrm{T}$ cell differentiation mediated by retinoic acid. Science 317: 256-260.

20. Wang L, Yi T, Kortylewski M, et al. (2009): IL-17 can promote tumor growth through an IL-6-Stat3 signaling pathway. J Exp Med 206: 1457-1464.

21. Kato T, Furumoto H, Ogura T, et al. (2001): Expression of IL17 mRNA in ovarian cancer. Biochem Biophys Res Commun 282: 735-738.

22. Radosavljevic G, Ljujic B, Jovanovic I, et al. (2010): Interleukin-17 may be a valuable serum tumor marker in patients with colorectal carcinoma. Neoplasma 57: 135-144.

23. Muranski P, Boni A, Antony PA, et al. (2008): Tumor-specific Th17-polarized cells eradicate large established melanoma. Blood 112: 362-373.

24. Jovanovic DV, Di Battista JA, Martel-Pelletier J, et al. (1998): IL-17 stimulates the production and expression of proinflammatory cytokines, IL-beta and TNF-alpha, by human macrophages. J Immunol 160: 3513-3521.

25. Antonysamy MA, Fanslow WC, Fu F, et al. (1999): Evidence for a role of IL-17 in organ allograft rejection: IL-17 promotes the functional differentiation of dendritic cell progenitors. J Immunol 162: 577-584.

26. Mousavi SM, Montazeri A, Mohagheghi MA, et al. (2007): Breast cancer in Iran: an epidemiological review. Breast J 13: 383-391.

27. Liu ZJ, Yadav PK, Su JL, et al. (2009): Potential role of Th17 cells in the pathogenesis of inflammatory bowel disease. World J Gastroenterol 15: 5784-5788. 
28. Park H, Li Z, Yang XO, et al. (2005): A distinct lineage of $\mathrm{CD} 4 \mathrm{~T}$ cells regulates tissue inflammation by producing interleukin 17. Nat Immunol 6: 1133-1141.

29. Zhou Z, Sun W, Liang Y, et al. (2012): Fenofibrate inhibited the differentiation of $\mathrm{T}$ helper 17 cells in vitro. PPAR Res 2012: 145654.

30. Baharlou R, Ahmadi Vasmehjani A, Dehghani A, et al. (2014): Reduced interleukin-17 and transforming growth factor beta levels in peripheral blood as indicators for following the course of bladder cancer. Immune Netw 14: 156-163.

31. Zhang JP, Yan J, Xu J, et al. (2009): Increased intratumoral IL-17-producing cells correlate with poor survival in hepatocellular carcinoma patients. J Hepatol 50: 980-989.

32. Numasaki M, Fukushi J, Ono M, et al. (2003): Interleukin-17 promotes angiogenesis and tumor growth. Blood 101: 26202627.

33. Wang L, Yi T, Zhang W, et al. (2010): IL-17 enhances tumor development in carcinogen-induced skin cancer. Cancer Res 70: 10112-10120

34. Radosavljevic G, Ljujic B, Jovanovic I, et al. (2009): Interleukin-17 may be a valuable serum tumor marker in patients with colorectal carcinoma. Neoplasma 57: 135-144.

35. Kwon KA, Kim SH, Oh SY, et al. (2010): Clinical significance of preoperative serum vascular endothelial growth factor, interleukin-6, and C-reactive protein level in colorectal cancer. BMC Cancer 10: 203.

36. Ravishankaran P, Karunanithi R (2011): Clinical significance of preoperative serum interleukin-6 and C-reactive protein level in breast cancer patients. World J Surg Oncol 9: 18.

37. Weaver CT, Hatton RD (2009): Interplay between the TH17 and TReg cell lineages: a (co-) evolutionary perspective. Nat Rev Immunol 9: 883-889.

38. Hsu HC, Yang P, Wang J, et al. (2008): Interleukin 17-producing $T$ helper cells and interleukin 17 orchestrate autoreactive germinal center development in autoimmune BXD2 mice. Nat Immunol 9: 166-175.

39. Connolly EC, Freimuth J, Akhurst RJ. Complexities of TGF-beta targeted cancer therapy. Int J Biol Sci 2012; 8: 964-978. 